\title{
PCR identification of dermatophyte fungi Trichophyton rubrum, T. soudanense and T. gourvilii
}

\author{
D. LIU*+, L. PEARCE†, G. LILLEY†, S. COLOE*, R. BAIRD* and J. PEDERSEN* \\ * Melbourne Pathology, Collingwood, Victoria 3066 and †CSIRO Health Science and Nutrition, Parkville, \\ Victoria 3052, Australia
}

\begin{abstract}
Diagnosis of dermatophytosis employing conventional laboratory procedures has been complicated by the slow growth and varied morphological features shown by dermatophytes. After analysis of the nucleotide base sequences of a 1.2-kb fragment amplified from a dermatophyte fungus Trichophyton rubrum by arbitrarily primed PCR with random primer OPD18, a pair of primers (TR1F and TR1R) was designed and evaluated for specific identification of $T$. rubrum. The sensitivity of the primers TR1F and TR1R was high, as a specific PCR band of $c .600 \mathrm{bp}$ was detected from as little as $7 \mathrm{pg}$ of $T$. rubrum DNA. By examining 92 dermatophyte strains and clinical isolates, it was found that this pair of primers reacted in PCR with T. rubrum, T. soudanense and T. gourvilii through formation of the specific fragment of $600 \mathrm{bp}$, but not with any other of the dermatophyte species or varieties, fungi, yeasts or bacteria tested. As T. rubrum is one of the most frequently isolated dermatophyte fungi, and $T$. soudanense and $T$. gourvilii are relatively uncommon in many parts of the world, these primers can be used for rapid, sensitive and specific identification and differentiation of $T$. rubrum from other fungi and micro-organisms.
\end{abstract}

\section{Introduction}

Dermatophytes are keratinophilic fungi responsible for causing dermatophytosis (or tinea/ringworm) in man and animals. Of the three recognised dermatophyte genera (Epidermophyton, Microsporum and Trichophyton), Trichophyton is the most common and complex, containing over 15 species and several varieties within the species $T$. mentagrophytes [1,2], and displaying considerable variations in their morphological characteristics and geographical distribution. For example, whereas $T$. rubrum is cosmopolitan and accounts for the bulk of the clinical isolations in many parts of the world, T. soudanense and T. gourvilii are mainly found in patients from the trans-Sudan belt and central African regions [1]. Often different dermatophyte species produce similar symptoms which are difficult to distinguish through clinical examination. Conse-

Received 20 Feb. 2001; revised version received 20 July 2001; accepted 26 July 2001.

Corresponding author: Dr D. Liu (donl@petermac. unimelb.edu.au).

$\Varangle$ Present address: Department of Pathology, Peter MacCallum Cancer Institute, St Andrews Place, East Melbourne, Victoria 3002, Australia. quently, characterisation by microscopy and in-vitro culture is required for appropriate diagnosis and treatment as well as epidemiological prevention of the infection. Microscopy provides a rapid screen for mycotic elements in clinical specimens, but it is nonspecific and shows a sensitivity of only $85 \%$ in detecting fungal elements [1]. In-vitro culture is sensitive and specific; however, the long incubation period (up to 4 weeks) represents a significant drawback for rapid diagnosis and treatment.

The application of nucleic acid amplification procedures such as PCR in recent years has greatly enhanced phylogenic determination and identification of dermatophyte fungi. The use of arbitrarily primed PCR (APPCR) amplification techniques can rapidly distinguish 23 of the 25 dermatophyte species examined through the generation of characteristic band patterns [3-7]. Nevertheless, species determination based on the detection of intricate and sometimes complex band patterns generated by the arbitrarily primed PCR can be a technically demanding task. The development of species-specific primers and probes for individual dermatophytes would offer a more practical and precise method of detection, and further improve the specificity of nucleic acid-based assays for dermatophytes. Indeed, 
the benefits of this latter approach have been clearly highlighted by the recent application of a $T$. rubrum specific probe derived from the highly variable ITS 2 region of the rDNA operon for precise determination of the dermatophyte concerned [8]. Moreover, the identification of $M$. canis-specific primers from randomly amplified DNA fragment has also enhanced the laboratory differentiation of $M$. canis from other micro-organisms [9].

In the present study, through analysis of the nucleic acid base sequences of fragments amplified from a $T$. rubrum isolate with random primer OPD18 in the arbitrarily primed PCR, specific oligonucleotide primers were designed and evaluated with a collection of dermatophyte reference strains and clinical isolates, with the aim of achieving rapid, sensitive and precise determination of T. rubrum from other dermatophyte species and micro-organisms.

\section{Materials and methods}

\section{Organisms}

Isolation of dermatophytes was routinely performed in this laboratory from infected skin, nail and hair samples of human patients. The samples were initially examined by microscopy for mycotic elements by suspending a small proportion of the samples in a drop of examination buffer - $(0.5 \mathrm{ml}$ of Blankophor BA 267\% (Bayer Australia, Melbourne, Australia) $0.1 \mathrm{w} / \mathrm{v}$, $0.5 \mathrm{ml}$ of $\mathrm{KOH} 10 \% \mathrm{w} / \mathrm{v}$ and glycerol $50 \mu \mathrm{l}$ ) - and examined by fluorescent microscopy. The rest of the sample was inoculated on to Dermasel Agar (Oxoid, Medvet, Adelaide, Australia) and Sabouraud's Dextrose Agar (Oxoid) and cultured at $26^{\circ} \mathrm{C}$ for up to 4 weeks. The identification of the dermatophyte isolates obtained were achieved by conventional microscopic and culture techniques.

A collection of 92 dermatophyte isolates comprising 16 Trichophyton species or varieties, 8 Microsporum species and 1 Epidermophyton species was examined (Table 1). Other than the 16 strains that originated from either the American Type Culture Collection (ATCC) or reference collections in Australia and New Zealand) (Table 1), all dermatophyte isolates were from clinical samples examined in this laboratory. A further 24 other fungal, yeast and bacterial strains or isolates were included for assessment of the specificity of the oligonucleotide primers developed (Table 1).

\section{Extraction of genomic DNA}

Genomic DNA was prepared from fungi and other micro-organisms with a rapid mini-preparation procedure [10]. To a $1.5 \mathrm{ml}$ Eppendorf tube containing $500 \mu \mathrm{l}$ of lysis buffer (400 mM Tris-HCl, pH 8.0, $60 \mathrm{~mm}$ EDTA, pH 8.0, $150 \mathrm{mM} \mathrm{NaCl}$, SDS 1\% w/v), a small portion of mycelium grown on Dermasel Agar or Sabouraud Dextrose Agar in primary culture was added using a sterile tooth pick, with which the mycelia were disrupted. The tube was then left at room temperature for $10 \mathrm{~min}$. After adding $150 \mu \mathrm{l}$ of potassium acetate, $\mathrm{pH} 4.8(5 \mathrm{M}$ potassium acetate $60 \mathrm{ml}$, glacial acetic acid $11.5 \mathrm{ml}$, distilled water $28.5 \mathrm{ml}$ ), the tube was vortex mixed briefly, and cellular debris and precipitated proteins were removed by centrifugation at $>10000 \mathrm{~g}$ for $1 \mathrm{~min}$. The supernate was transferred to another $1.5-\mathrm{ml}$ Eppendorf tube and centrifuged again as above. After transferring the supernate to a new $1.5-\mathrm{ml}$ Eppendorf tube, an equal volume of iso-propyl alcohol was added. The tube was mixed briefly by inversion, centrifuged at $>10000 \mathrm{~g}$ for $2 \mathrm{~min}$ and the supernate was discarded. The resultant DNA pellet was washed in $300 \mu \mathrm{l}$ of ethanol $70 \% \mathrm{v} / \mathrm{v}$. After centrifuging at $10000 \mathrm{~g}$ for $1 \mathrm{~min}$, the supernate was discarded. The DNA pellet was air dried and dissolved in $50 \mu \mathrm{l}$ of $1 \times$ TE; $1 \mu \mathrm{l}$ of the purified DNA was used in $25-50 \mu \mathrm{l}$ of PCR mixture. Genomic DNA from other fungi, yeasts and bacteria was isolated similarly.

\section{Arbitrarily primed PCR}

The arbitrarily primed PCR was performed essentially as described previously [4]. The reaction mixture (30 $\mu \mathrm{l})$ was made up of $1 \mu \mathrm{l}$ of genomic DNA (from the 50 - $\mu \mathrm{l}$ mini-preparation), $50 \mathrm{mM} \mathrm{KCl}, 10 \mathrm{mM}$ Tris$\mathrm{HCl}$ (pH 9.0), $10 \mathrm{mM} \mathrm{NaCl}, 0.5 \mathrm{mM} \mathrm{DTT,} 2.5 \mathrm{mM}$ $\mathrm{MgCl}_{2}$, Triton X-100 $0.1 \% \mathrm{w} / \mathrm{v}, 200 \mu \mathrm{M}$ of each dNTP (dATP, dCTP, dGTP and dTTP), Taq DNA polymerase (Life Technologies, Melbourne, Australia) $0.6 \mathrm{U}$ and 15 pmol of random primer OPD18 (5'-GAGAGCCAAC-3') (Operon Technologies, Alameda, USA). The PCR amplification was conducted in a Gene$\mathrm{Amp}^{\mathrm{TM}}$ PCR System 9600 (Perkin Elmer, Applied Biosystems, Melbourne, Australia) with the following protocol: 1 cycle of $95^{\circ} \mathrm{C}$ for $60 \mathrm{~s}$ and 38 cycles of $95^{\circ} \mathrm{C}$ for $15 \mathrm{~s}, 36^{\circ} \mathrm{C}$ for $45 \mathrm{~s}$ and $72^{\circ} \mathrm{C}$ for $90 \mathrm{~s}$. A tube with no template DNA was used as a negative control. Upon completion, $5 \mu \mathrm{l}$ of $10 \times$ DNA sample buffer (bromophenol blue $10 \mathrm{mg}$, glycerol $27 \mathrm{ml}$, SDS $1 \%$ $10 \mathrm{ml}, 0.5 \mathrm{M}$ EDTA (pH 8.0) $10 \mathrm{ml}$, distilled water $3 \mathrm{ml}$ ) was added to each tube, from which $10 \mu \mathrm{l}$ was electrophoresed (at $5 \mathrm{~V} / \mathrm{cm}$ ) in an agarose $1.5 \% \mathrm{w} / \mathrm{v}$ gel in $1 \times$ TAE buffer in the presence of ethidium bromide $0.5 \mu \mathrm{g} / \mathrm{ml}$, and subsequently examined under UV light. The sizes of the resultant PCR products were estimated against a reference DNA mol. wt marker $(\lambda$ HindIII + EcoRI $)$.

\section{DNA cloning and sequencing}

The DNA fragments of interest amplified in AP-PCR with random primer OPD18 were cut out from agarose gels and purified with a Geneclean kit (BIO 101, Integrated Sciences, Melbourne, Australia). The purified DNA fragments were then cloned into plasmid vector (pCR-Script Amp SK (+); Stratagene, Integrated Sciences, Melbourne, Australia) according to the 
Table 1. Dermatophyte, fungal, yeast and bacterial strains/isolates examined

\begin{tabular}{|c|c|c|c|}
\hline & Organism & Source* & $\begin{array}{l}\text { Number } \\
\text { tested }^{\dagger}\end{array}$ \\
\hline & Dermatophyte & & \\
\hline 1 & Trichophyton ajelloi & Clinical (MPD109) & 1 \\
\hline 2 & T. concentricum & A/NZ (MPD110) & 1 \\
\hline 3 & T. equinum var. autotrophicum & A/NZ (MPD111) & 1 \\
\hline 4 & T. gourvilii & A/NZ (MPD120) & 1 \\
\hline 5 & T. mentagrophytes var. erinacei & A/NZ (MPD118) & 2 \\
\hline 6 & T. mentagrophytes var. interdigitale & Clinical (MPD97) & 10 \\
\hline 7 & T. mentagrophytes var. mentagrophytes & A/NZ (MPD154) & 5 \\
\hline 8 & T. mentagrophytes var. nodulare & Clinical (MPD40) & 4 \\
\hline 9 & T. mentagrophytes var. quinckeanum & A/NZ (MPD116) & 5 \\
\hline 10 & T. rubrum & ATCC 28188 & 20 \\
\hline 11 & T. schoenleinii & A/NZ (MPD112) & 1 \\
\hline 12 & T. soudanense & A/NZ (MPD132) & 7 \\
\hline 13 & T. terrestre & A/NZ (MPD113) & 1 \\
\hline 14 & T. tonsurans & CDC B5408 & 10 \\
\hline 15 & T. verrucosum & Clinical (MPD103) & 2 \\
\hline 16 & T. violaceum & Clinical (MPD47) & 10 \\
\hline 17 & Microsporum audouinii & Clinical (MPD57) & 3 \\
\hline 18 & M. canis & ATCC42888 & 2 \\
\hline 19 & M. cookei & A/NZ (MPD55) & 2 \\
\hline 20 & M. ferrugineum & A/NZ (MPD114) & 2 \\
\hline 21 & M. fulvum & $\mathrm{A} / \mathrm{NZ}$ (MPD121) & 1 \\
\hline 22 & M. gypseum & Clinical (MPD58) & 3 \\
\hline 23 & M. nanum & Clinical (MPD39) & 1 \\
\hline 24 & M. persicolor & A/NZ (MPD115) & 2 \\
\hline \multirow[t]{3}{*}{25} & Epidermophyton floccosum & Clinical (MPD74) & 5 \\
\hline & Subtotal & & 92 \\
\hline & Fungi & & \\
\hline 26 & Aspergillus fumigatus & Clinical (MPF14) & 2 \\
\hline 27 & Fusarium oxysporum & Clinical (MPF19) & 2 \\
\hline 28 & Scytalidium dimidiatum & Clinical (MPF62) & 2 \\
\hline 29 & Scopulariopsis brevicaulis & Clinical (MPF75) & 2 \\
\hline \multirow[t]{3}{*}{30} & Alternaria spp. & Clinical (MPF244) & 1 \\
\hline & Subtotal & & 9 \\
\hline & Yeast & & \\
\hline 31 & Candida albicans & Clinical (MPY21) & 2 \\
\hline \multirow[t]{3}{*}{32} & Cryptococcus neoformans & Clinical (MPY26) & 2 \\
\hline & Subtotal & & 4 \\
\hline & Bacteria & & \\
\hline 33 & Bacillus cereus var. mycoides & ATCC11778 & 1 \\
\hline 34 & B. subtilis & ATCC6633 & 1 \\
\hline 35 & Enterobactor cloacae & ATCC23355 & 1 \\
\hline 36 & Escherichia coli & ATCC25922 & 1 \\
\hline 37 & Micrococcus luteus & ATCC9341 & 1 \\
\hline 38 & Proteus vulgaris & ATCC13315 & 1 \\
\hline 39 & Pseudomonas aeruginosa & ATCC27853 & 1 \\
\hline 40 & Salmonella typhimurium & ATCC14028 & 1 \\
\hline 41 & Serratia marcescens & ATCC8100 & 1 \\
\hline 42 & Staphylococcus aureus & ATCC25923 & 1 \\
\hline \multirow[t]{3}{*}{43} & S. epidermis & ATCC12228 & 1 \\
\hline & Subtotal & & 11 \\
\hline & Total & & 116 \\
\hline
\end{tabular}

\footnotetext{
${ }^{*}$ The exemplary strains and isolates were obtained from either ATCC, Australia and New Zealand collections, or clinical isolations. The numbers in brackets are the exemplary strain/isolate identification numbers recorded at Melbourne Pathology.

$\dagger$ The total strain/isolate number of each species/subspecies examined included the exemplary strains/isolates.
}

manufacturer's instructions. To determine the nucleotide base sequences of clones containing DNA fragments of interest, double-strand plasmid DNA templates suitable for sequencing were isolated from an overnight culture of Escherichia coli strain Epicurian Coli XL1-Blue (Stratagene) by means of Wizard Miniprep DNA Purification Systems (Promega Corporation, Sydney, Australia). DNA sequencing was done with AmpliTaq DNA Polymerase (Dye Terminator Cycle Sequencing Ready Reaction, Perkin Elmer) and universal pUC/M13 forward and reverse primers in an automatic sequencer (AB307, Perkin Elmer).

\section{PCR with specific primers}

The PCR with specific oligonucleotide primers was conducted in $25 \mu \mathrm{l}$ of reaction mixture. The reaction mixture consisted of $1 \mu \mathrm{l}$ of genomic DNA (from the $50 \mu 1$ mini-preparation), $50 \mathrm{mM} \mathrm{KC1}, 10 \mathrm{mM}$ Tris- $\mathrm{HCl}$ (pH 9.0), $10 \mathrm{mM} \mathrm{NaCl}, 0.5 \mathrm{mM}$ DTT, $2.5 \mathrm{mM} \mathrm{MgCl}_{2}$, 
Triton X-100 $0.1 \%, 200 \mu \mathrm{M}$ of each dNTP (dATP, dCTP, dGTP and dTTP), Taq DNA polymerase $0.5 \mathrm{U}$ and $50 \mathrm{pmol}$ each of specific primers. The PCR was performed in a GeneAmp ${ }^{\mathrm{TM}}$ PCR System 9600 (Perkin Elmer) with the following protocol: $95^{\circ} \mathrm{C}$ for $60 \mathrm{~s}$ and 35 cycles of $95^{\circ} \mathrm{C}$ for $15 \mathrm{~s}, 55^{\circ} \mathrm{C}$ for $30 \mathrm{~s}$ and $72^{\circ} \mathrm{C}$ for $60 \mathrm{~s}$. A tube with no template DNA was used as a negative control. The resultant PCR products were detected as for the AP-PCR.

The sensitivity of the specific PCR primers was determined with serial dilutions (i.e., 1, 0.5, 0.25, $0.125,0.062,0.031,0.015$ and $0.007 \mathrm{ng}$ ) of purified DNA, the concentration of which was determined at an absorbance of $260 \mathrm{~nm}\left(\mathrm{~A}_{260}\right)$ in a spectrophotometer. The specificity of these primers was assessed by testing DNA prepared from various fungal, yeast and bacterial strains and isolates described above.

\section{Results}

\section{Arbitrarily primed PCR}

Examination of various dermatophytes and other fungi with random primer OPD18 in AP-PCR has been reported previously $[4,7]$. As shown in Fig. 1 and summarised in Table 2, with random primer OPD18 in the AP-PCR, two bands of 3.1 and $1.2 \mathrm{~kb}$ were amplified from the genomic DNA of T. rubrum (Fig. 1, lane 2), two bands of 3.2 and $1.2 \mathrm{~kb}$ from $T$. soudanense (Fig. 1, lane 3) and two bands of 3.1 and $1.2 \mathrm{~kb}$ from $T$. gourvilii (Fig. 1, lane 4). Other dermatophytes and fungi formed DNA band patterns somewhat different from these three species, and no band was produced from the negative control (without template DNA) (Fig. 1, Table 2; some data not shown).

\section{Analysis of DNA sequences of the specific clone}

A major fragment of $c$. $1.2 \mathrm{~kb}$, generated from the genomic DNA of the T. rubrum type strain (ATCC 28188) in the AP-PCR with OPD18, was cut out, purified, cloned and sequenced. The resultant insert was c. $0.7 \mathrm{~kb}$ in length. A forward primer (TR1F: 5' GAACACAGCAGTGCATTCGA-3') and a reverse primer (TR1R: 5'-TATGCATCTGCAGCGGAAAG-3') were derived from this cloned insert, and custom synthesised (Gene Works, South Australia).

\section{Assessment of specific primers $T R 1 F$ and $T R 1 R$}

By examining serial dilutions (ranging from $1 \mathrm{ng}$ to $0.007 \mathrm{ng}$ ) of purified DNA from T. rubrum strain ATCC 28188, the sensitivity fo the specific oligonucleotide primers TR1F and TR1R was found to be high, as a specific PCR band of $c .600 \mathrm{bp}$ was detected with DNA amounts down to $0.007 \mathrm{ng}$ (or $7 \mathrm{pg}$ ), but not with a negative (no DNA) control with ethidium bromide stain (data not shown).

The specificity of the primer pair TR1F and TR1R was evaluated in PCR with the 92 dermatophyte and 24 other fungal, yeast and bacterial stains and isolates (Table 1). As shown in Fig. 2 and Table 2, a band of $600 \mathrm{bp}$ was generated in PCR with these primers from genomic DNA of T. rubrum (Fig. 2, lane 2), $T$. soudanense (Fig. 2, lane 3) and T. gourvilii (Fig. 2, lane 4) only; but not from other dermatophytes, fungi and yeasts, or 11 common bacteria, or the negative control (without DNA template) (Fig. 2, Table 2 and data not shown). Of the $20 \mathrm{~T}$. rubrum and $7 \mathrm{~T}$. soudanense strains and isolates examined, many displayed variations in colony morphology and colour in comparison with the type strain, yet they all formed a specific band of $600 \mathrm{bp}$ in the PCR (data not shown).

\section{Discussion}

Diagnosis of dermatophytosis has been complicated by the existence of multiple species and varieties within the dermatophytes, and also hampered by the sometimes slow-growing and varied morphological features shown by dermatophyte isolates. The fact that various dermatophyte species require distinct treatment regimens, and that differentiation of anthropophilic dermatophytes from zoophilic organisms benefits epidemiological prevention of the infection has necessitated the development of rapid, sensitive and specific diagnostic methods.

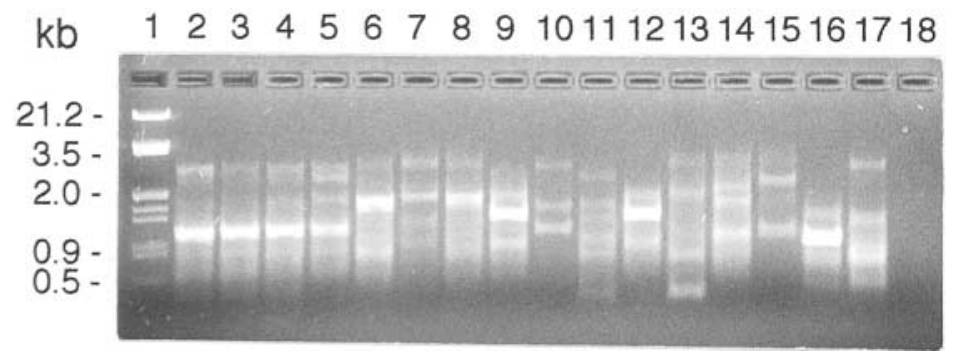

Fig. 1. Examination of dermatophyte DNA products generated in the arbitrarily primed PCR with random primer OPD18. Lane 1, DNA mol. wt marker ( $\lambda$ HindIII $+E c o$ RI in kb; 2, DNA products amplified from T. rubrum isolate; 3, T. soudanense; 4, T. gourvilii; 5, T. violaceum; 6, T. mentagrophytes var. interdigitale; 7, T. mentagrophytes var. quinckeanum; 8, T. tonsurans; $\mathbf{9}$, M. canis; 10, M. audouinii; 11, M. cookei; 12, M. ferrugineum; 13, M. fulvum; 14, M. gypsum; 15, M. nanum; 16, E. floccosum; 17, Alternaria spp.; 18, negative control with no template DNA. 
Table 2. Summary of PCR products amplified from dermatophyte and other fungal DNA (as shown in Figs. 1 and 2)

\begin{tabular}{|c|c|c|c|}
\hline Lane & Content & $\begin{array}{l}\text { AP-PCR products* } \\
(\mathrm{kb})\end{array}$ & $\begin{array}{l}\text { Specific } \\
\text { PCR products }{ }^{\dagger} \\
(600 \text { bp) }\end{array}$ \\
\hline 1 & Mol. wt marker $(\lambda$ HindIII $+E c o \mathrm{RI})$ & & \\
\hline 2 & Trichophyton rubrum & $3.1,1.2$ & + \\
\hline 3 & T. soudanense & $3.2,1.2$ & + \\
\hline 4 & T. gourvilii & $3.1,1.2$ & + \\
\hline 5 & T. violaceum & $3.2,2.5,1.9,1.2$ & - \\
\hline 6 & T. mentagrophytes var. interdigitale & $3.2,2.0,0.9$ & - \\
\hline 7 & T. mentagrophytes var. quinckeanum & $3.2,2.1,1.1,0.8$ & - \\
\hline 8 & T. tonsurans & $3.2,1.8,1.2$ & - \\
\hline 9 & Microsporum canis & $2.0,1.2,0.9$ & - \\
\hline 10 & M. audouinii & $2.8,1.4,1.1$ & - \\
\hline 11 & M. cookei & $2.5,1.5,0.9,0.7$ & - \\
\hline 12 & M. ferrugineum & $2.0,1.3,0.9$ & - \\
\hline 13 & M. fulvum & $3.3,2.1,0.8,0.3$ & - \\
\hline 14 & M. gypseum & $3.2,2.1,1.6,1.0$ & - \\
\hline 15 & M. nanum & $2.2,1.1$ & - \\
\hline 16 & Epidermophyton floccosum & $1.8,1.0,0.8$ & - \\
\hline 17 & Alternaria spp. & $3.2,1.2,0.8,0.5$ & - \\
\hline 18 & Negative control & - & - \\
\hline
\end{tabular}

* The AP-PCR was performed with random primer OPD18 as shown in Fig. 1, and the product sizes estimated against the reference mol. wt marker $(\lambda H i n d+E c o R I)$.

${ }^{\dagger}$ The specific PCR was carried out with primers TR1F and TR1R as shown in Fig. 2.

In recent years, the use of nucleic acid amplification techniques has enabled vast improvement in phylogenetic analysis and diagnosis of dermatophyte fungi. Experimental studies exploiting the differences in the small (18S) [11] and large (25S) [12, 13] ribosomal RNA, as well as internal transcripted spacer regions $[8,14-18]$ of dermatophytes and other fungi, have resulted in a better understanding of the phylogeny of pathogenic fungi including dermatophytes. The use of the AP-PCR has made it possible to differentiate 23 of the 25 dermatophyte species and varieties under investigation [3-7]. The development of a T. rubrumspecific probe [8] from the highly variable ITS 2 region of the ribosomal DNA operon as well as $M$. canisspecific primers from randomly amplified DNA fragment [9] has further contributed to improved identification and differentiation of T. rubrum and M. canis from other fungi and micro-organisms.

In this report, based on the DNA sequences of a $1.2-\mathrm{kb}$ fragment produced from a T. rubrum strain in the APPCR with random primer OPD18, two oligonucleotide primers (TR1F and TR1R) were designed. The sensitivity of these primers was high, as a specific PCR band of c. $600 \mathrm{bp}$ was detected with amounts of DNA as low as $7 \mathrm{pg}$. After examining 92 dermatophyte strains and isolates representing various Trichophyton and Microsporum species and varieties as well as $E$. floccosum, it was shown that this primer pair recognised DNA from T. rubrum, T. soudanense and T. gourvilii, generating a band of $600 \mathrm{bp}$ in PCR, but did not recognise DNA from any other of the dermatophytes, fungi, yeasts or common bacteria tested.

Compared with conventional phenotypic techniques such as in-vitro culture for T. rubrum identification, PCR with the specific primers TR1F and TR1R is clearly superior in terms of sensitivity, specificity and speed. Because the PCR assay involves in-vitro amplification of target DNA, it is highly sensitive and rapid, with results available within a day from primary culture. Furthermore, as it is based on genotypic detection, the PCR test is specific and not affected by any morphological variations typically shown by dermatophyte fungi. This is supported by the observation that although many of the $20 \mathrm{~T}$. rubrum and $7 \mathrm{~T}$. soudanense strains and isolates under investigation demonstrated considerable morphological variations, they all produced a specific PCR band of $600 \mathrm{bp}$.

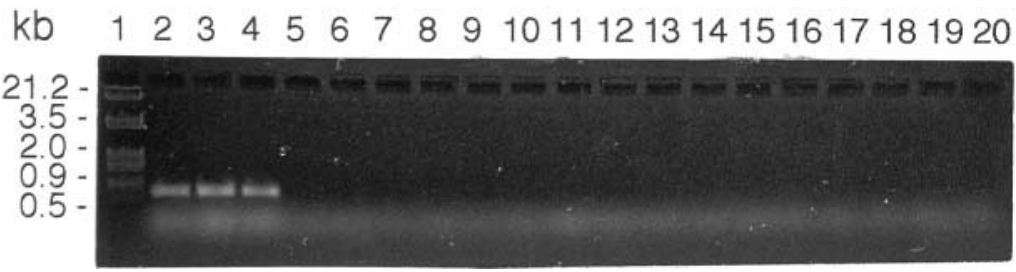

Fig. 2. Detection of specific PCR products through the use of oligonucleotide primers TR1F and TR1R. Lane 1, DNA mol. wt marker ( $\lambda$ HindIII + EcoRI) in kb; 2, DNA products amplified from T. rubrum isolate; 3, T. soudanense; $\mathbf{4}, T$. gourvilii; $\mathbf{5}, T$. violaceum; 6, T. mentagrophytes var. interdigitale; 7, T. mentagrophytes var. quinckeanum; 8, T. tonsurans; 9, M. canis; 10, M. audouinii; 11, M. cookei; 12, M. ferrugineum; 13, M. fulvum; 14, M. gypsum; 15, M. nanum; 16, E. floccosum; 17, Alternaria spp.; 18, negative control with no template DNA. 
Moreover, the PCR technique is relatively straightforward as it does not demand specialist skills for morphological and biochemical identification of dermatophyte species.

The fact that the specific primers TR1F and TR1R reacted with $T$. rubrum, $T$. soudanense and $T$. gourvilii suggests that these three dermatophytes may be very closely related. Indeed, previous studies with the APPCR showed that of the four random primers employed, three (OPAA11, OPAA17 and OPU15) were unable to distinguish among T. rubrum, T. soudanense and T. gourvilii, whilst the fourth random primer (OPD18), which was also used in this study, produced negligible differences among the three dermatophyte species $[4,7]$. Other research groups also demonstrated the close relationship between $T$. rubrum and $T$. soudanense through examining the ITS regions of these dermatophytes $[12,14,15]$. It is possible that there may have been some over-classification among the dermatophyte species $T$. rubrum, T. soudanense and T. gourvilii. Future experimental studies on the detailed genetic structures of these species would help clarify the issue.

Considering that T. rubrum is the most frequently isolated dermatophyte species, and that $T$. soudanense and $T$. gourvilii are relatively uncommon in many parts of the world, the application of PCR with the specific oligonucleotide primers TR1F and TR1R would be valuable in helping rapid differentiation of T. rubrum (T. soudanense and T. gourvilii) from other dermatophytes and micro-organisms. With the future development of a DNA purification procedure from nails, skin and hair, the use of these specific primers in a PCR combined with an enzymic detection system will vastly improve the efficiency and specificity of laboratory diagnosis of the common dermatophyte fungus $T$. rubrum.

\section{References}

1. Rippon JW. Medical mycology: the pathogenic fungi and the pathogenic actinomycetes, 3rd edn. Philadelphia, WB Saunders. 1988 .
2. Weitzman I, Summerbell RC. The dermatophytes. Clin Microbiol Rev 1995; 8: 240-259.

3. Liu D, Coloe S, Pedersen J, Baird R. Use of arbitrarily primed polymerase chain reaction to differentiate Trichophyton dermatophytes. FEMS Microbiol Lett 1996; 136: 147-150.

4. Liu D, Coloe S, Baird R, Pedersen J. Molecular determination of dermatophyte fungi using the arbitrarily primed polymerase chain reaction. Br J Dermatol 1997; 137: 351-355.

5. Liu D, Coloe S, Baird R, Pedersen J. PCR identification of Trichophyton mentagrophytes var. interdigitale and T. mentagrophytes var. mentagrophytes dermatophytes with a random primer. J Med Microbiol 1997; 46: 1043-1046.

6. Liu D, Coloe S, Baird R, Pedersen J. Rapid differentiation of Microsporum dermatophytes based on arbitrarily primed PCR amplification. Opportun Pathogens 1997; 9: 3-6.

7. Liu D, Coloe S, Baird R, Pedersen J. Application of PCR to the identification of dermatophyte fungi. $J$ Med Microbiol 2000; 49: 493-497.

8. El Fari M, Tietz H-J, Presber W, Sterry W, Gräser Y. Development of an oligonucleotide probe specific for Trichophyton rubrum. Br J Dermatol 1999; 141: 240-245.

9. Liu D, Pearce L, Lilley G, Coloe S, Baird R, Pedersen J. A specific PCR assay for the dermatophyte fungus Microsporum canis. Med Mycol 2001; 39: 215-219.

10. Liu D, Coloe S, Baird R, Pedersen J. Rapid mini-preparation of fungal DNA for PCR. J Clin Microbiol 2000; 38: 471.

11. Harmsen D, Schwinn A, Weig M, Brocker EB, Heesemann J. Phylogeny and dating of some pathogenic keratinophilic fungi using small subunit ribosomal RNA. J Med Vet Mycol 1995; 33: 299-303.

12. Leclerc MC, Philippe H, Gueho E. Phylogeny of dermatophytes and dimorphic fungi based on large subunit ribosomal RNA sequence comparisons. J Med Vet Mycol 1994; 32: 331-341.

13. Haynes KA, Westerneng TJ, Fell JW, Moens W. Rapid detection and identification of pathogenic fungi by polymerase chain reaction amplification of large subunit ribosomal RNA. J Med Vet Mycol 1995; 33: 319-325.

14. Jackson CJ, Barton RC, Evans EGV. Species identification and strain differentiation of dermatophyte fungi by analysis of ribosomal-DNA intergenic spacer regions. J Clin Microbiol 1999; 37: 931-936.

15. Summerbell RC, Haugland RA, Li A, Gupta AK. RNA gene internal transcribed spacer 1 and 2 sequences of asexual, anthropophilic dermatophytes related to Trichophyton rubrum. J Clin Microbiol 1999; 37: 4005-4011.

16. Gräser Y, El Fari M, Vigalys R et al. Phylogeny and taxonomy of the family Arthrodermataceae (dermatophytes) using sequence analysis of the ribosomal ITS region. Med Mycol 1999; 37: $105-114$.

17. Makimura K, Tamura $\mathrm{Y}$, Mochizuki $\mathrm{T}$ et al. Phylogenetic classification and species identification of dermatophyte strains based on DNA sequences of nuclear ribosomal internal transcribed spacer 1 regions. J Clin Microbiol 1999; 37: 920-924.

18. Makimura K, Mochizuki T, Hasegawa A, Uchida K, Saito H, Yamaguchi H. Phylogenetic classification of Trichophyton mentagrophytes complex strains based on DNA sequences of nuclear ribosomal internal transcribed spacer 1 regions. J Clin Microbiol 1998; 36: 2629-2633. 